\title{
Hak Veto Menteri Tenaga Kerja dan Transmigrasi dan Perlindungan Hukum bagi Rakyat dalam Penyelesaian Perselisihan Perburuhan
}

\author{
Mila Karmila Adi
}

\begin{abstract}
There is a govemment's intervention in the Labour Dispute Resolution Law, called Veto, that is belong to the Minister of The Employment and Transmigration. The Veto influences the parties'right to have a just decision in their labour dispute resolution process because it can be made by the Minister's will. The Veto should be diminished or even wiped out from the process because it only gives a political decision that influence the juridical decision of the Central Institution (Panitia Penyelesaian Perselisihan Perburuhan Pusat Panitia Pusat.
\end{abstract}

\section{Pendahuluan}

Suatu hubungan kerja yang ideal menunjukkan adanya pelaksanaan kewajiban dan hak dari pihak pekerja maupun pengusaha. Pelaksanaan kewajiban dan hak ini harus sesuai dengan berbagai ketentuan dalam peraturan perundang-undangan, perjanjian kerja, peraturan perusahaan, perjanjian perburuhan, maupun dalam hukum kebiasaan masyarakat.

Kenyataan yang sering terjadi adalah hubungan kejja ini seringkali tidak tejalin secara harmoni, bahkan banyak terjadi ketimpangan yang sulit dihindari terutama dalam pelaksanaan kewajiban dan hak yang ada di dalamnya, sehingga terjadilah perselisihan yang dapat mengakhiri hubungan kerja yang ada.

Perselisihan antara pekerja dan pengusaha merupakan suatu kejadian yang wajar, namun perselisihan ini akan menimbuikan akibat-

akibat yang akan merugikan salah satu pihak maupun kedua belah pihak dan bahkan pihak lain (masyarakat dan pemerintah). Menyadari akibat-akibat dari perselisihan yang terjadi, untuk itu diperlukan pengaturan yang secara khusus mengatur tentang penyelesaian perselisihan perburuhan yang terjadi.

Peraturan perundang-undangan yang mengatur tentang penyelesaian perselisihan perburuhan secara khusus adalah Undangundang (UU) Nomor 22 Tahun 1957 tentang Penyelesaian Perselisihan Perburuhan. UU ini mengatur penyelesaian perselisihan secara bipartit (dua pihak) dan penyelesaian secara tripartit (tiga pihak) yang dapat dilakukan melalui mekanisme penyelesaian perselisihan secara wajib dan secara sukarela.

Mekanisme penyelesaian perselisihan secara wajib terdiri dari beberapa tahapan 
penyelesaian mulai dari penyelesaian melalui Pegawai Perantara di Departemen Tenaga Kerja dan Transmigrasi, ${ }^{1}$ Panitia Penyelesaian Perselisihan Perburuhan Daerah ${ }^{2}$ maupun Panitia Penyelesaian Perselisihan Perburuhan Pusat, ${ }^{3}$ sampai pada Menteri Tenaga Kerja dan Transmigrasi. ${ }^{4}$

Penyelesaian perselisihan perburuhan secara wajib merupakan suatu prosedur yang dilaksanakan di lingkungan pemerintahan, yang dalam hal ini adalah di lingkungan Departemen Tenaga Kerja dan Transmigrasi. Prosedur ini sesuai dengan ketentuan Pasal 48 Undang-undang Nomor 5 Tahun 1986 tentang Peradilan Tata Usaha Negara (PTUN) dan Penjelasannya, merupakan suatu upaya administratif.

Penyelesaian perselisihan perburuhan secara wajib sebagai suatu upaya administratif, maka upaya ini harus dilaksanakan terlebih dahulu sebelum perselisihan tersebut diajukan ke PTUN. Kewajiban untuk melakukan upaya administratif di bidang perburuhan/ketenagakejjaan hanya dilakukan sampai pada tingkat Panitia Pusat, sedangkan untuk penyelesaian perselisihan pada tingkat Menakertrans tidak dapat dilakukan atas kehendak para pihak yang berselisih, akan tetapi hanya dapat dilakukan atas inisiatif dari Menakertrans.
Proses penyelesaian perselisihan perburuhan oleh Menakertrans ini merupakan suatu hak yang diberikan oleh Undangundang untuk membatalkan atau menunda pelaksanaan suatu keputusan Panitia Pusat demi memelihara ketertiban umum dan melindungi kepentingan negara. ${ }^{5}$ Kewenangan Menakertrans ini disebut dengan hak veto dari Menakertrans. ${ }^{6}$

Menakertrans dalam rangka menyelesaikan suatu perselisihan perburuhan diberi kewenangan untuk mengeluarkan surat keputusan pembatalan atau penundaan suatu keputusan Panitia Pusat dan sekaligus mengatur akibat-akibat dari pembatalan atau penundaan tersebut.

Dalam rangka melindungi kepentingan dari para pihak yang terkait ternyata tidak ada suatu tata cara yang diatur yang diberikan bagi para pihak untuk mengajukan keberatan atas veto yang dilakukan oleh Menakertrans. Padahal dalam melakukan veto tersebut Menakertrans mempunyai kebebasan yang sangat besar, terutama karena di dalam UU Nomor 22 Tahun1957 tidak ada penjelasan lebih lanjut mengenai batasan atau pengertian dari "ketertiban umum dan melindungi kepentingan umum". Dengan demikian, Menakertrans mempunyai kewenangan besar untuk secara luas atau secara sempit mengartikan istilah tersebut.

'Dengan adanya UU Nomor 22 Tahun 1999 tentang Pemerintahan Daerah saat ini Pegawai Perantara berkedudukan pada Dinas Tenaga Kerja dan Transmigrasi Daerah Kabupaten atau Kota.

2Selanjutnya disebut sebagai Panitia Daerah, yang berkedudukan pada Daerah Propinsi.

${ }^{3}$ Selanjutnya disebut sebagai Panitia Pusat, yang berkedudukan pada Departemen Tenaga Kerja dan Transmigrasi đi DKI Jakarta.

¿Selanjutnya disebut Menakertrans.

5Pasal 17 UU Nomor 22 Tahun 1957.

'Penjelasan Umum UU Nomor 22 Tahun 1957. 
Di samping adanya kewenangan menafsirkan batasan dari "ketertiban umum dan melindungi kepentingan umum", maka penundaan ataupun pembatalan putusan Panitia Pusat oleh Menakertrans akan memperpanjang proses penyelesaian perselisihan perburuhan yang ada, sehingga akan memperlambat penyelesaian perselisihan tersebut.

\section{Tata Cara Pelaksanaan Hak Veto Menakertrans Berdasarkan Peraturan Menteri Tenaga Kerja (dan Transmigrasi) Nomor 1 Tahun 1995}

Undang-undang Nomor 22 Tahun 1957 sebagai peraturan pokok yang mengatur penyelesaian perselisihan di bidang ketcnagakerjaan tidak mengatur secara jelas tentang tata cara pelaksanaan hak veto Menakertrans dalam mekanisme penyelesaian secara wajib.

Pengaturan lebih lanjut mengenai hak veto Menakertrans terdapat dalam Peraturan Menteri Tenaga Kerja ${ }^{7}$ (dan Transmigrasi) Nomor PER-01/MEN/1995 tentang Tata Cara Pembatalan atau Penundaan Pelaksanaan Putusan P4P (atau Panitia Pusat-pen.) tertanggal 6 Februari 1995.

Pada dasarnya hak veto Menakertrans untuk membatalkan atau menunda pelaksanaan putusan Panitia Pusat adalah hak penuh dari Menakertrans dan penggunaan hak tersebut bukan atas permintaan dari pihak-pihak yang berperkara. Penggunaan hak veto tersebut dilakukan setelah berunding dengan Menteri-menteri yang mempunyai wakil dalam Panitia Pusat dan bila perlu dengan Menteri teknis yang terkait.

Hak veto Menakertrans digunakan apabila dipandang bahwa putusan Panitia Pusat dapat membahayakan ketertiban umum dan merugikan kepentingan negara, untuk itu kepaniteraan Panitia Pusat harus menyampaikan secara tertulis isi putusan Panitia Pusat kepada Menakertrans untuk dinilai, dalam waktu paling lama 7 (tujuh) hari setelah putusan itu ditetapkan.

Akibat-akibat lebih lanjut dari pembatalan atau penundaan pelaksanaan putusan Panitia Pusat ditetapkan dengan pembentukan Tim Asistensi oleh Menakertrans, yang keanggotaannya terdiri dari wakil-wakil Departemen yang mempunyai wakil dalam Panitia Pusat yang dibentuk dengan Keputusan Menakertrans. Departemendepartemen yang mempunyai wakil dalam kepanitiaan Panitia Pusat adalah terdiri dari Kementerian Tenaga Kerja dan Transmigrasi, Kementerian Keuangan, Kementerian Pertanian, Kementerian Perindustrian (dan Perdagangan-pen.), dan Kementerian Perhubungan.

Pengaturan akibat veto Menakertrans ditetapkan dengan Keputusan Menakertrans. dan bila perlu dapat dilaksanakan sebagai putusan Panitia Pusat. Hal ini berarti bahwa keputusan Menakertrans tersebut dapat dilaksanakan menurut cara untuk melaksanakan putusan Panitia Pusat dan mempunyai kekuatan berlaku sebagaimana putusan Panitia.

Jika keputusan Menakertrans tersebut, sebagaimana putusan Panitia Pusat, yang

${ }^{7}$ Selanjutnya disebut sebagai Permenaker. 
dapat mulai dilaksanakan tidak ditaati secara sukarela, maka pelaksanaannya dapat dimintakan kepada Pengadilan Negeri di Jakarta oleh pihak yang berkepentingan. Dengan demikian keputusan itu untuk selanjutnya dilaksanakan menurut aturan yang berlaku untuk melaksanakan suatu putusan perdata.

Barang siapa yang tidak tunduk pada keputusan Menakertrans yang mulai dapat dilaksanakan, dapat pula dituntut secara hukum pidana. Pengawasan atas pelaksanaan Keputusan Menteri, yang dilaksanakan sebagai putusan Panitia Pusat tersebut, dilakukan oleh Pegawai Pengawas Ketenagakerjaan.

Permenaker Nomor 1 Tahun 1995 dikeluarkan dalam rangka memberikan kejelasan tata cara dan kedudukan dari hak veto Menakertrans dalam mekanisme penyelesaian perselisihan secara wajib. Hal ini. dikarenakan sebelum adanya Permenaker tersebut ternyata pelaksanaan hak veto Menakertrans tidak sesuai dengan prosedur yang seharusnya.

Hak Veto Menakertrans dalam Penyelesaian Perselisihan Perburuhan Sebagai Suatu Freies Ermessen

Hak veto Menakertrans dalam penyelesaian perselisihan perburuhan merupakan suatu bentuk freies ermessen, yaitu kebebasan bertindak dalam batas-batas tertentu. ${ }^{8}$ Kebebasan bertindak ini harus diberi batasan-batasan tertentu, karena freies ermessen telah menjadi salah satu sumber sengketa antara Pejabat Tata Usaha Negara dengan warga negara sehingga dapat diajukan ke Peradilan Tata Usaha Negara (PTUN).

Gugatan ke PTUN tersebut dapat diajukan terhadap Keputusan Menteri Tenaga Kerja. dan Transmigrasi yang diambil berdasarkan kewenangan untuk membatalkan atau menunda putusan Panitia Pusat, apabila para pihak, yaitu pengusaha dan/atau pekerja, tidak dapat menerima Keputusan tersebut. Bahkan kemungkinan karena para pinak yang bersangkutan sebenarnya sudah dapat menerima putusan dari Panitia Pusat, dan dengan adanya veto dari Menaker akan mengurangi atau bahkan menghilangkan hak dari para pihak dari segi kepastian hukum dan keadilan.

Freies emessen ${ }^{9}$ yang dilaksanakan dan dituangkan dalam suatu bentuk keputusan (=ketetapan/beschikking), jika menimbulkan kerugian bagi seseorang atau badan hukum perdata, dapat dinilai sebagai keputusan yang bertentangan dengan peraturan perundangundangan yang berlaku (onrechtmatige overheidsdaad) atau dinilai sebagai perbuatan (keputusan) yang dikeluarkan atas dasar sewenang-wenang (willikeur atau a bus de droit) atau penyalahgunaan wewenang (detoumement de pouvoir).

Ketiga perbuatan itu, menurut Sjachran Basah, ${ }^{10}$ sangat sukar untuk dipisah-pisahkan,

\footnotetext{
${ }^{8}$ Sjachran Basah, Eksistensi dan Tolok Ukur Badan Peradilan Administrasi di Indonesia (Bandung: Alumni, 1997), hlm. 219.

${ }^{9}$ S.F.Marbun, Peradilan Administrasi Negara dan Upaya Administratif di Indonesia (Yogyakarta: Liberty, 1997), hlm.13.

${ }^{10}$ Sjachran Basah, op.cit., hlm. 238.
} 
karena pada hakikatnya merupakan perbuatan yang melawan hukum dan mendatangkan kerugian kepada pihak yang terkena. Bahkan apabila diperhatikan dan diamati, sering ternyata bahwa perbuatan administrasi negara itu. lebih berupa suatu "beleid" yang didasarkan atas kebijaksanaan pemerintah dari pada suatu perbuatan hukum yang sungguh-sungguh, disebabkan adanya freies ermessen yang pada asasnya mengizinkan untuk mengutamakan doelmatigheid."

\section{Campur Tangan Pemerintah dalam Rangka. Perlindungan Hukum bagi Rakyat}

Negara, dalam pengertian yang abstrak, dapat diartikan sebagai badan hukum yang mempunyai tujuan tertentu. Dalam teori negara kesejahteraan, tujuan negara tidak lain adalah untuk mewujudkan kesejahteraan setiap warga negaranya. Konsep keterlibatan negara dalam bidang ekonomi, untuk pertama kali dikemukakan oleh Beveridge, seorang anggota Parlemen Inggris dalam reportnya, yang mengandung suatu program sosial: pemerataan pendapatan masyarakat, kesejahteraan sosial sejak manusia lahir sampai meninggal, lapangan kerja, pengawasan atas upah oleh pemerintah, dan usaha dalam bidang pendidikan.12

Asas kebebasan berkontrak yang merupakan ciri khas dan bahkan landasan dalam bidang hukum yang menunjang suatu ekonomi pasar, yang di kemudian hari menjadi tidak terkendali telah menjadikan pihak sosialekonomi lemah menjadi semakin tersudut, telah dibatasi dengan "demi kepentingan umum atau demi pemerataan. ${ }^{.13}$

Keterlibatan negara untuk campur tangan dalam setiap aspek kehidupan masyarakat yang semakin besar, menimbulkan konsekuensi kekuasaan dan kebebasan yang semakin besar dari pihak Administrasi Negara. Agar kekuasaan dan kebebasan tersebut tidak disalahgunakan dan perlindungan hukum bagi rakyat tetap terjamin, maka diperlukan pengawasan terhadap Administrasi Negara.

Pengawasan tersebut dapat dilakukan secara ekstern maupun intern. Khusus dalam bidang administrasi, maka pengawasan ekstem dilakukan melalui Peradilan Administrasi/ PTUN. Pengawasan secara intern dapat dilakukan melalui badan-badan di lingkungan pemerintahan sendiri, baik melalui atasan yang mempunyai hubungan hirarkis maupun melalui panitia yang terdiri dari beberapa orang yang ahli dalam bidang tertentu.

Mekanisme penyelesaian perselisihan perburuhan terdiri dari mekanisme "penyelesaian secara wajib"14 (compulsory arbitration) dan mekanisme "penyelesaian secara sukarela" (voluntary arbitration) yang diserahkan kepada Juru/Dewan Pemisah. Mekanisme penyelesaian perselisihan secara wajib bukan merupakan suatu peradilan khusus di bidang

${ }^{11 / \text { bid., him. } 246 .}$

${ }^{12}$ Muchsan, Peradilan Administrasi Negara (Yogyakarta: Liberty, 1981), him. 1.

${ }^{13}$ C.F.G.Sunaryati Hartono, Politik Hukum Menuju Satu Sistem Hukum Nasional (Bandung: Alumni, 1991), him. 96.

14Iman Soepomo, Pengantar Hukum Perburuhan (Jakarta: Djambatan, 1995), hlm. 99. 
ketenagakerjaan, akan tetapi merupakan suatu "peradilan administrasi semu (tidak murni), ${ }^{115}$ yaitu sebagai salah satu upaya administratif sebagaimana yang diatur dalam Pasal 48 Undang-undang Nomor 5 Tahun 1986 tentang Peradilan Tata Usaha Negara. Upaya administratif ini merupakan bagian dari pengertian peradilan administrasi dalam arti luas. ${ }^{16}$

Upaya administratif dalam penyelesaian perselisihan perburuhan tersebut di dalamnya terdapat tiga institusi yang berwenang untuk bertindak sebagai perantara maupun pemutus perselisihan, yaitu Pegawai Perantara, Panitia Daerah/Pusat, dan Menakertrans.

Ketiga institusi dalam penyelesaian perselisihan perburuhan tersẹbut secara hirarkis berada dalam satu lingkup departemen, yaitu Depnakertrans. Akan tetapi menurut Sri Soemantri sebagaimana dikutip oleh S.F.Marbun, ${ }^{17}$ meskipun badan yang memutus itu berada di lingkungan pemerintahan sendiri dan di bawah pengaruhnya, badan tersebut dalam melaksanakan tugas dan kewajibannya harus selalu berdasarkan atas hukum dan memperlakukan setiap warga negara sesuai dengan harkat dan martabatnya sebagai manusia, tanpa membeda-bedakannya.

Upaya administratif (administratieve beroep, oneigenlijke administratieve rechtspraak) adalah suatu prosedur yang dapat ditempuh oleh seseorang atau badan hukum perdata yang tidak puas terhadap suatu keputusan tata usaha negara. Prosedur tersebut dilakukan di lingkungan pemerintahan sendiri dan terdiri dari atas dua bentuk, yaitu banding administratif dan prosedur keberatan. ${ }^{18}$

Van Praag, ${ }^{19}$ dalam Sjachran Basah, menyatakan bahwa yang ditentang pada "oneigenlijke administratieve rechtspraak" ialah perbuatan yang dilakukan oleh administrasi negara dalam kualitasnya sebagai badan hukum umum (openbare rechtspersoon) yang disebut "onmiddelijk bestuur". Hal ini berarti, bahwa administrasi negara bertindak bukan sebagai badan yang berdiri sendiri, yang menentukan peraturan hukum (orgaan van rechtsvaststeling) untuk suatu keadaan konkrit. Bahwa di dalam "ịuridiekesfeer" administrasi negara sebagai badan hukum umum mempunyai hak menentukan hukum, akan tetapi wewenang itu di dapat secara langsung dari instansi yang lebih tinggi, sehingga tidak merupakan badan yang berdiri sendiri.

Hukum Administrasi Negara mengatur bahwa tindakan/perbuatan dari administrasi negara harus didasarkan pada suatu dasar kewenangan yang sah, yaitu harus didasarkan pada suatu aturan hukum tertentu, baik aturan hukum tertulis maupun aturan hukum tidak tertulis. Termasuk di dalam tindakan administrasi negara yang harus berdasarkan aturan hukum adalah tindakan administrasi negara yang didasarkan atas freies ermessen.

${ }^{15}$ Sjachran Basah. op.cit., hlm. 63.

${ }^{16}$ Rochmat Soemitro, Masalah Peradilan Administrasi dalam Hukum Pajak dilndonesia (Bandung: Eresco, 1976), hlm. 51.

${ }^{17}$ Ibid., hlm. 71.

${ }^{18}$ Penjelasan Pasal 48 UU Nomor 5 Tahun 1986.

${ }^{19}$ Dalam Sjachran Basah. op.cit., hlm. 61. 
Apabila ternyata tindakan administrasi negara tersebut bertentangan atau melanggar aturan hukum yang ada, maka demi perlindungan hukum kepada masyarakat harus ada proses atau jalur untuk meminta pertanggungjawaban secara hukum kepada administrasi negara yang melakukan pelanggaran hukum tersebut. Perlindungan hukum bagi rakyat ini adalah termasuk dalam dan sejalan dengan konsep rechtsstaat maupun konsep the rule of law.

Perlindungan hukum yang diberikan kepada masyarakat apabila terjadi tindakan admnistrasi negara yang bertentangan atau melanggar hukum dibedakan dua macam, ${ }_{1}{ }^{20}$ yaitu perlindungan hukum yang preventif dan perlindungan hukum yang represif. Pada perlindungan hukum yang preventif kepada rakyat diberikan kesempatan untuk mengajukan keberatan (inspraak) atau pendapatnya sebelum suatu keputusan pemerintah mendapat bentuk yang definitif. Perlindungan hukum preventif bertujuan untuk mencegah terjadinya sengketa sedangkan perlindungan hukum represif bertujuan untuk menyelesaikan sengketa.

Sarana perlindungan hukum baik represif maupun preventif sangat penting diadakan karena terutama dikaitkan dengan asas freies ermessen (discretionaire bevoegheid). Untuk sarana perlindungan hukum yang preventif $\mathrm{di}$ Indonesia belum ditemukan pengaturan secara khusus. ${ }^{21}$

Peradilan Administrasi Negara/PTUN sebagai sarana perlindungan hukum represif, . maka untuk perkara-perkara yang menyangkut tindakan administrasi negara atau tindak pemerintahan diajukan ke peradilan tersebut. Peradilan administrasi (murni) di dalamnya juga tercakup peradilan administrasi semu yang dalam hal ini disebut upaya administratif. ${ }^{22}$

\section{Hak Veto Menakertrans sebagai Upaya Perlindungan Hukum bagi Rakyat}

Menakertrans dalam mekanisme penyelesaian perselisihan perburuhan secara organisatoris berkedudukan sebagai pejabat administrasi negara tertinggi yang berwenang untuk memutuskan suatu perselisihan perburuhan. Kedudukan Menakertrans ini adalah sebagai suatu badan hukum umum (openbare rechtspersoon), yang berarti bahwa Menakertrans bertindak bukan sebagai badan yang berdiri sendiri yang menentukan peraturan hukum untuk suatu keadaan yang konkrit.

Kewenangan yang diberikan oleh peraturan perundang-undangan (UU Nomor 22 Tahun 1957) kepada Menakertrans dalam proses penyelesaian perselisihan perburuhan untuk melakukan pembatalan atau penundaan suatu keputusan dari Panitia Pusat, merupakan suatu hak untuk menentukan hukum dan merupakan kewenangan yang bersifat atributif. Di dalam proses penyelesaian perselisihan perburuhan, pada dasarnya kewenangan ini tidak termasuk sebagai proses penyelesaian perselisihàn yang harus dilalui oleh para pihak. Hal ini dikarenakan

${ }^{20}$ Philipus M.Hadjon, Perlindungan Hukum bagi Rakyat di Indonesia (Surabaya: Bina llmu, 1997), HIm. 2. 21/bid., hlm. 3-4.

22Pasal 48 UU Nomor 5 Tahun 1986 dan Penjelasannya, bandingkan pula dengan pendapat S.F.Marbun, op.cit., him. 65 dan Sjachran Basah, op.cit., hlm. 117. 
Mila Karmila Adi. Hak Veto Menteri Tenaga Kerja dan Transmigrasi ...

kewenangan tersebut merupakan hak penuh dari Menakertrans yang dapat digunakan apabila alasan yang menjadi sahnya tindakan Menakertrans terpenuhi, yaitu untuk memelihara ketertiban umum dan melindungi kepentingan negara. Dengan demikian eksistensi hak veto Menakertrans ini tidak berasal dari kehendak para pihak yang bersengketa, baik dari pihak pekerja maupun pengusaha.

Hak Menakertrans dapat dilakukan dengan syarat bahwa Menakertrans setelah menilai putusan Panitia Pusat harus mempertimbangkannya bersama-sama dengan Menteri-menteri yang mempunyai wakil di Panitia Pusat, bahwa putusan tersebut mengganggu ketertiban. umum dan kepentingan negara. Keputusan tentang pembatalan atau penundaan pelaksanaan putusan Panitia Pusat harus juga mengatur akibat-akibat dari pembatalan atau penundaan itu.

Pelaksanaan dari hak veto ini ternyata cukup banyak terjadi diajukan oleh para pihak yang bersengketa. Hal ini dapat dilihat pada jumlah putusan Panitia Pusat yang dimintakan peninjauan kembali (veto) kepada Menakertrans selama periode tahun 19901995, sebagaimana dalam Tabel 1 dan 2. Hal ini tentu saja menjadi pertanyaan, karena pada dasarnya hak veto tersebut merupakan wewenang penuh dari Menakertrans untuk melakukan veto setelah berunding dengan Menteri-menteri yang terkait.

Tabel 1.

Perbandingan antara Jumlah Putusan Panitia Pusat dengan Jumlah Putusan yang diajukan Veto (1991-1995)

\begin{tabular}{|c|l|c|c|c|c|c|}
\hline No. Urut & \multicolumn{1}{|c|}{ Keterangan } & $\begin{array}{c}\text { TA. } \\
1991\end{array}$ & $\begin{array}{c}\text { TA. } \\
1992\end{array}$ & $\begin{array}{c}\text { TA. } \\
1993\end{array}$ & $\begin{array}{c}\text { TA. } \\
1994\end{array}$ & $\begin{array}{c}\text { TA. } \\
1995\end{array}$ \\
\hline 1. & Putusan P4P & 859 & 855 & 848 & 1114 & 1283 \\
\hline 2. & Veto yang diajukan & 119 & 101 & 98 & 79 & 227 \\
\hline
\end{tabular}

Sumber: Kepaniteraan Panitia Pusat Tahun 1996. 
Tabel 2.

Putusan Panitia Pusat yang dimintakan veto/peninjauan kembali kepada Menaker. (Menurut pihak yang meminta)

\begin{tabular}{|c|l|c|c|c|c|c|}
\hline \multirow{2}{*}{ No. Urut } & \multicolumn{1}{|c|}{ Pihak-pihak } & $\begin{array}{c}\text { TA. } \\
\text { 1990/1991 }\end{array}$ & $\begin{array}{c}\text { TA. } \\
1991 / 1992\end{array}$ & $\begin{array}{c}\text { TA. } \\
\text { 1992/1993 }\end{array}$ & $\begin{array}{c}\text { TA. } \\
1993 / 1994\end{array}$ & $\begin{array}{c}\text { TA. } \\
1994 / 1995\end{array}$ \\
\hline 1. & Pengusaha & 69 & 52 & 42 & 50 & 138 \\
2. & Pekerja & 50 & 49 & 56 & 29 & 86 \\
3. & Pengusaha dan Pekerja & - & - & - & - & 3 \\
\cline { 2 - 7 } & Jumlah & 119 & 101 & 98 & 79 & 227 \\
\hline
\end{tabular}

Sumber: Kepaniteraan Panitia Pusat Tahun 1996.

Kesalahan prosedur untuk adanya suatu veto terhadap putusan Panitia Pusat ini disadari oleh pihak Menakertrans yang kemudian mengeluarkan Permenaker Nomor 1 Tahun 1995 tentang Tata Cara Pembatalan atau Penundaan Pelaksanaan Putusan Panitia Pusat. Permenaker tersebut menegaskan bahwa hak veto merupakan wewenang penuh dari Menakertrans dan tidak dapat dimintakan oleh para pihak yang bersengketa.

Pihak kepaniteraan Panitia Pusat ${ }^{23}$ menyatakan bahwa dengan adanya Permenaker tersebut Menakertrans tidak pernah lagi mengeluarkan hak vetonya atas permintaan para pihak yang bersengketa. Lebih lanjut dijelaskan oleh Jafar Sodikin, bahwa selama periode kepemimpinan di Depnakertrans,
Menteri Abdul Latief hanya melakukan veto satu kali. Untuk periode kepemimpinan Menteri Fahmi Idris, belum pernah melakukan veto terhadap putusan Panitia Pusat.

Hak veto Menakertrans ini ternyata merupakan suatu pelaksanaan dari freies Ermessen yang cukup besar dari Menakertrans, karena tidak adanya batasan pengertian dari "ketertiban umum" maupun "kepentingan negara" untuk dapat terlaksananya hak itu. Sehingga Menakertrans mempunyai kewenangan yang luas untuk menafsirkan apakah suatu putusan Panitia Pusat melanggar ketertiban umum dan kepentingan negara atau tidak. Namun demikian, hak veto sebagai suatu pelaksanaan kewenangan bertindak dari Menakertrans

23Keterangan dari Jafar Sodikin pada tanggal 3 Maret 1999 di Kantor Kepaniteraan Panitia Pusat di Jakarta. 
sudah seharusnyalah dibatasi oleh peraturan perundang-undangan yang berlaku maupun aturan-aturan yang tidak tertulis, yang dalam hal ini adalah Asas-asas Umum Pemerintahan yang Layak (AAUPL), untuk memberikan perlindungan bagi para pihak yang bersengketa.

UU Nomor 5 Tahun 1986 tentang Peradilan Tata Usaha Negara (PTUN) bahkan menyatakan bahwa penyelesaian perselisihan perburuhan adalah termasuk sebagai suatu upaya administratif yang harus dilaluj oleh para pihak yang bersengketa dalam bidang ketenagakerjaan. ${ }^{24}$

Penyelesaian perselisihan perburuhan secara wajib sebagai suatu upaya admimistratif pada dasarnya hanya sampai pada tingkat Panitia Pusat, yaitu dengan didasarkan pada hak dari para pihak yang tidak merasa puas dengan putusan Panitia Daerah maka yang bersangkutan dapat mengajukan banding kepada Panitia Pusat.

Penyelesaian perselisihan perburuhan yang dilakukan oleh Menakertrans melalui hak veto terhadap putusan Panitia Pusat bukanlah termasuk di dalam upaya administratif. Hal ini dikarenakan pelaksanaan hak veto tersebut dilakukan dengan inisiatif dari pihak Menakertrans atas dasar "ketertiban umum" dan "kepentingan negara". Jadi terdapat campur tangan yang aktif dari pihak Menakertrans sebagai administrasi negara, yang dalam hal ini mungkin saja tidak dikehendaki oleh para pihak yang bersengketa.

Proses penyelesaian perselisihan perburuhan oleh Menakertrans bukanlah proses penyelesaian tertinggi yang wajib dilalui oleh para pihak yang berselisih. Dengan demikian eksistensi Menakertrans dalam proses penyelesaian perselisihan perburuhan secara wajib bukan merupakan bagian dari upaya administratif. Bahkan dalam Penjelasan Pasai 48 UU Nomor 5 Tahun 1986 hanya menyebutkan putusan Panitia Pusat sebagai salah satu contoh dari putusan yang dapat diajukan banding administratifnya, bukannya Keputusan Menaker yang memveto putusan Panitia Pusat itu.

Para pihak yang bersengketa dalam perselisihan perburuhan pada dasarnya ingin agar perselisihan yang terjadi dapat diselesaikan secepat mungkin dan seadil mungkin, baik dengan adanya campur tangan pihak ketiga maupun antara para pihak sendiri. Sengketa yang mereka ajukan untuk diselesaikan melalui mekanisme wajib, yaitu dengan adanya campur tangan pihak ketiga (tripartit), pada kenyataan dapat saja harus melalui proses yang cukup panjang.

Perselisihan yang diselesaikan melalui Pegawai Perantara maupun Panitia Daerah/ Pusat, pada dasamya merupakan kehendak para pihak yang bersengketa tersebut apabila mereka merasa tidak puas atas putusan sebelumnya. Demikian pula apabila mereka berkehendak untuk mengajukannya ke Pengadilan. Tinggi Tata Usaha Negara (PTTUN) sebagai upaya lebih lanjut berdasarkan UU Nomor 5 Tahun 1986. Akan tetapi dengan adanya hak veto Menakertrans, yang merupakan hak penuh dari Menaker dan tidak dapat dimintakan oleh para pihak yang bersengketa, maka hal ini merupakan suatu campur tangan pihak pejabat administrasi

2"Lihat kembali Pasat 48 dan Penjelasannya. 
negara yang dilakukan secara sepihak, yaitu termasuk dalam perbuatan hukum publik.

Pelaksanaan hak veto dari Menakertrans dengan kebebasan yang lias untuk mengartikan batasan "ketertiban umum" dan "kepentingan negara", pada dasarnya sudah melanggar kepentingan para pihak yang bersengketa, yang mungkin sudah menyetujui putusan dari Panitia Pusat. Untuk itu perlu adanya suatu proses lebih lanjut untuk memberikan hak bagi para pihak yang bersengketa apabila putusan Panitia Pusat yang sudah mereka setujui dibatalkan atau ditunda pelaksanaannya oleh Menakertrans.

Upaya untuk memberikan perlindungan bagi para pihak yang bersengketa ini kemungkinan dapat dilakukan melalui PTUN, yaitu langsung ke PTTUN sebagai suatu upaya banding administratif. Hal ini dikarenakan hak veto jika perlu dapat dilaksanakan sebagai putusan Panitia Pusat, ${ }^{25}$ yaitu dapat dimintakan eksekusinya ke Pengadilan Negeri di Jakarta oleh pihak yang terkena putusan tersebut, dapat dilaksanakan menurut aturan yang berlaku untuk melaksanakan putusan perdata, dan kepada pihak yang tidak tunduk dapat dituntut secara hukum pidana.

Pengajuan gugatan atas hak veto Menakertrans kemungkinan juga dapat dilakukan dengan melihat kedudukan keputusan tersebut, yang pada dasarnya memenuhi syarat-syarat sebagai suatu keputusan (Keputusan Tata Usaha Negaral KTUN) ${ }^{26}$ yaitu "Suatu penetapan tertulis yang dikeluarkan oleh Badan atau Pejabat Tata
Usaha Negara, yang berisi tindakan hukum tata usaha negara, yang berdasarkan peraturan perundang-undangan yang berlaku, yang bersifat konkrit, individual dan final, yang menimbulkan akibat hukum bagi seseorang atau badan hukum perdata".

Pemenuhan syarat-syarat suatu KTUN untuk menjadi objek sengketa PTUN, yang dalam hal ini adalah Keputusan Menakertrans untuk membatalkan atau menunda putusan Panitia Pusat, adalah sebagai berikut: 1 . Keputusan Menakertrans tersebut secara formal dalam bentuk tertulis, walaupun syarat tertulis ini pada dasarnya bukan ditujukan pada bentuk formalnya akan tetapi kepada isinya, sehingga akan memudahkan dalam segi pembuktiannya. 2. Keputusan ini dikeluarkan oleh Menakertrans sebagai administrasi negara atau Pejabat Tata Usaha Negara dalam menyelenggarakan pemerintahan negara atau fungsi eksekutif berdasarkan ketentuan Pasal 17 UU Nomor 22 Tahun 1957. 3. Keputusan itu bersifat konkrit, yaitu objek yang diputuskan dalam Keputusan tersebut menyangkut keputusan untuk membatalkan atau menunda suatu putusan perselisihan perburuhan. 4 . Keputusan itu bersifat individuil, yaitu menyangkut kejelasan para pihak yang sedang berselisih, baik dari pihak pengusaha/perkumpulan pengusaha dan pekerja/serikat pekerja yang tertentu. 5. Keputusan itu juga bersifat final, karena keputusan tersebut tidak memerlukan persetujuan instansi lain dan karenanya sudah dapat menimbulkan akibat hukum.

${ }^{25}$ Pasal 17 ayat (4) UU Nomor 22 Tahun 1957 dan Penjelasannya.

${ }^{26}$ Pasal 1 point 3 UU Nomor 5 Tahun 1986. 
Dengan demikian apabila dilihat lebih lanjut keputusan Menakertrans tersebut telah memenuhi syarat sebagai objek sengketa PTTUN, maka pihak PTTUN wajib memeriksa, mengadili dan memutus perkara tersebut.

\section{Simpulan}

Eksistensi Hak veto Menakertrans dalam penyelesaian perselisihan perburuhan sangat berpengaruh terhadap proses penyelesaian perselisihan perburuhan yang terjadi, terutama pada kebebasan para pihak untuk menerima atau menolak putusan Panitia Pusat, karena Menakertrans dapat menggunakan hak vetonya tersebut dengan kebebasan yang luas.

Perlindungan hukum secara normatif yang diatur untuk para pihak yang berselisih apabila suatu putusan Panitia Pusat dikenai veto oleh Menakertrans, temyata tidak ada. Akan tetapi secara teoritis, upaya untuk memberikan perlindungan hukum bagi para pihak yang bersengketa dengan adanya hak veto Menakertrans adalah dengan mengajukan keputusan Menaketrans tersebut ke PTTUN, karena hak veto tersebut temyata merupakan suatu keputusan yang dapat menjadi objek sengketa atau memenuhi syarat-syarat sebagai suatu KTUN. $\square$

\section{Daftar Pustaka}

C.F.G.Sunaryati Hartono. Politik Hukum Menuju Satu Sistem Hukum Nasional. Bandung: Alumni, 1991

Iman Soepomo. Pengantar Hukum Perburuhan. Jakarta: Djambatan, 1995.

Muchsan. Peradilan Administrasi Negara. Yogyakarta: Liberty, 1981.

Philipus M.Hadjon. Perlindungan Hukum bagi Rakyat di Indonesia. Surabaya: Bina Ilimu, 1987.

Rochmat Soemitro. Masalah Peradilan Administrasi dalam Hukum Pajak di Indonesia. Bandung: Eresco, 1976.

Sjachran Basah. Eksistensi dan Tolok Ukur Badan Peradilan Administrasi di Indonesia Bandung: Alumni, 1997.

S.F. Marbun. Peradilan Administrasi Negara dan Upaya Administratif di Indonesia. Yogyakarta: Liberty, 1997.

Undang-Undang Nomor 22 Tahun 1957 tentang Penyelesaian Perselisihan Perburuhan.

Undang-Undang Nomor 5 Tahun 1986 Peradilan Tata Usaha Negara.

Undang-undang Nomor 22 Tahun 1999 tentang Pemerintahan Daerah.

Peraturan Menteri Tenaga Kerja Nomor PER01/MEN/1995 tentang Tata Cara Pembatalan atau Penundaan Pelaksanaan Putusan Panitia Pusat. 